\title{
Mite Pests of Southern Highbush Blueberry in Florida ${ }^{1}$
}

\author{
Oscar E. Liburd, Lorena Lopez, and Doug Phillips ${ }^{2}$
}

\section{Introduction}

Several mite species attack southern highbush blueberries (SHB), including the southern red mite (Oligonychus ilicis McGregor (Acari: Tetranychidae)), the false spider mite or flat mite (Brevipalpus yothersi Baker), and the blueberry bud mite (Acalitus vaccinii Keifer). The southern red mite is the most important mite pest attacking blueberry plants in the southeastern US (Lopez and Liburd 2020). The false spider mite is a secondary leaf-feeding mite pest that was reported attacking southern highbush blueberry in 2016 (Akyazi et al. 2017). Unlike the southern red mite and the false spider mite, the blueberry bud mite has been a secondary pest in blueberries for more than 80 years, and management programs are available for this pest (Weibelzahl and Liburd 2017).

\section{Description and Life Cycle Life Cycle of Southern Red Mites}

In Florida, southern red mite populations continue to reproduce without any diapause, and populations persist and increase under optimal climatic conditions, generally between $60^{\circ} \mathrm{F}$ and $86^{\circ} \mathrm{F}$, reaching high numbers during the fall (Denmark et al. 2012). Their life cycle can be completed within two weeks under these conditions, and when overlapping generations occur (between $70^{\circ} \mathrm{F}$ and $81^{\circ} \mathrm{F}$ ) populations can double within five days, increasing their potential for substantial yield impact (Reis et al. 1997). Adults are similar in appearance to the red form of twospotted spider mites (Tetranychus urticae Koch) and other red Tetranychus species. Eggs are red to brown and spherical. Eggs hatch into pale six-legged larvae, while the nymphal stages have eight legs and become progressively darker and larger. The red eggs of southern red mites can be distinguished from the white eggs of twospotted spider mites. Southern red mite adults are about $0.4 \mathrm{~mm}$ in length and are red or brown to deep purple in color, with lightercolored legs. Females are slightly larger than males and have a more rounded body shape posteriorly, compared to the slender body of the males (Figure 1) (Knihinicki et al. 1999).

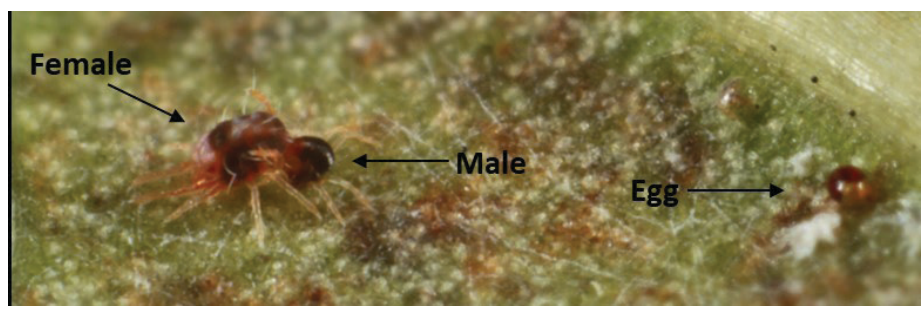

Figure 1. Southern red mite adult female and male mating, and one egg.

Credits: L. Buss, UF/IFAS

1. This document is ENY-1006, one of a series of the Entomology and Nematology Department, UF/IFAS Extension. Original publication date June 2020. Visit the EDIS website at https://edis.ifas.ufl.edu for the currently supported version of this publication.

2. Oscar E. Liburd, professor, Entomology and Nematology Department; Lorena Lopez, postdoctoral research associate, Entomology and Nematology Department; and Doug Phillips, blueberry Extension coordinator, UF/IFAS Gulf Coast Research and Education Center; UF/IFAS Extension, Gainesville, FL 32611.

The use of trade names in this publication is solely for the purpose of providing specific information. UF/IFAS does not guarantee or warranty the products named, and references to them in this publication do not signify our approval to the exclusion of other products of suitable composition. All chemicals should be used in accordance with directions on the manufacturer's label.

The Institute of Food and Agricultural Sciences (IFAS) is an Equal Opportunity Institution authorized to provide research, educational information and other services

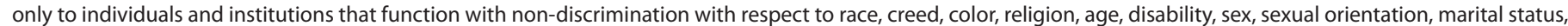

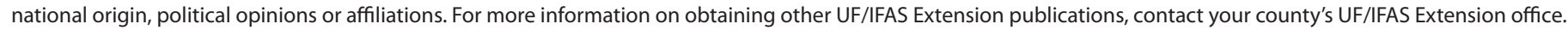
U.S. Department of Agriculture, UF/IFAS Extension Service, University of Florida, IFAS, Florida A \& M University Cooperative Extension Program, and Boards of County Commissioners Cooperating. Nick T. Place, dean for UF/IFAS Extension. 


\section{Life Cycle of False Spider Mites or Flat Mites}

Brevipalpus yothersi belongs to the group of mites known as flat mites or false spider mites. They can complete a life cycle in about 19 to 20 days at $77 \pm 1^{\circ} \mathrm{F}$ and $60 \pm 10 \%$ relative humidity $(\mathrm{RH})$. Eggs are elliptical and bright red to orange (Amaral et al. 2018). Adult flat mite females are approximately $0.3 \mathrm{~mm}$ long, flat, oval, and red-orange (Figure 2). Males and immature stages (larvae and nymphs) are smaller than females, but similar in appearance and color pattern (Akyazi et al. 2017).

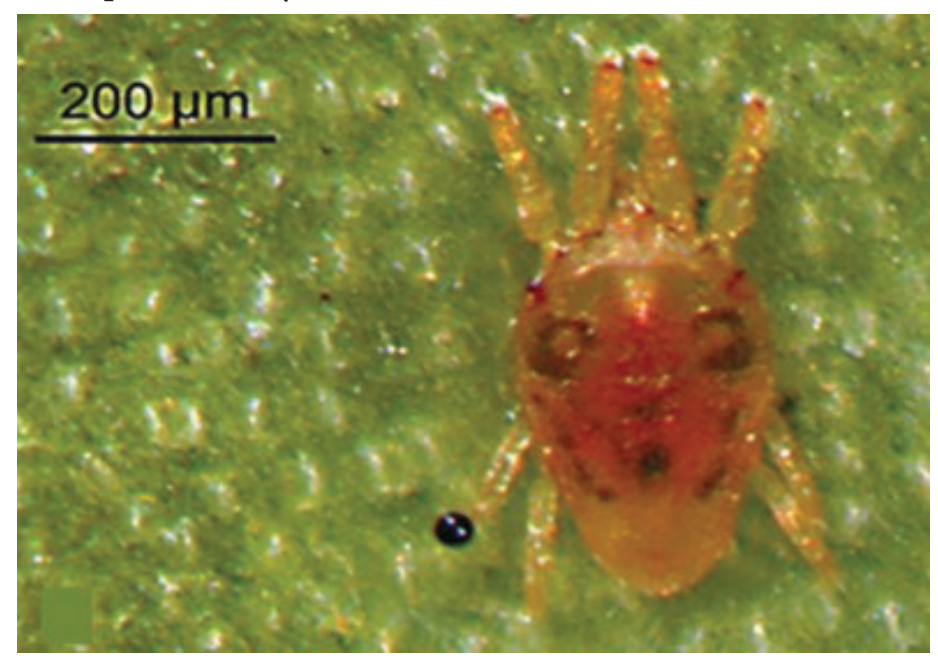

Figure 2. Female adult flat mite.

Credits: R. Akyazi, University of Ordu, Turkey

\section{Damage}

\section{Southern Red Mite Damage}

In SHB, southern red mites primarily infest the lower side of the leaves, resulting in the accumulation of white shed skins when populations reach high numbers (Figure 3 ). Bronze-colored leaves are the main symptom associated with southern red mite injury, and the intensity of the bronzing is proportional to the degree of internal leaf damage (Figure 4). Like most leaf-feeding mites, the southern red mite feeds on plant tissues by inserting their mouthparts into the leaf and removing cell contents, resulting in a photosynthesis rate decline (Lopez and Liburd 2020).

\section{Flat Mite or False Spider Mite Damage}

The characteristic symptoms associated with flat mite injury can include necrotic brown spots on leaves (Figure 5), stem browning, gall formation, brownish patches on the fruit surface, defoliation, and dieback, depending on the host plant species (Childers et al. 2003). In blueberry bushes, leaves heavily infested with flat mites often have necrotic brown spots (Figure 5). Infested leaves are sometimes infected with the bacteria Xylella sp. (Bacteria:
Xanthomonadales) that causes bacterial leaf scorch disease. Irregular leaf scorch, yellow coloration, and reduced plant vigor have often been associated with flat mite or false spider mite damage (Akyazi et al. 2017). Bacterial leaf scorch, caused by Xylella fastidiosa, has been established in Florida since 2006 (Phillips et al. 2019); however, the role of flat mites in the development and spread of $X$. fastidiosa in Vaccinium spp. has not yet been determined.

Brevipalpus yothersi has a strong association with the citrus leprosis virus complex and it is a vector of cytoplasmic leprosis viruses (Roy et al. 2015). Blueberry necrotic ring blotch virus (BNRBV) has been reported in Florida blueberry plantings (Phillips et al. 2019), and it is closely related to these viruses. BNRBV induces localized necrotic or chlorotic lesions like the characteristic symptoms associated with $B$. yothersi feeding. However, the potential role of false spider mites or flat mites as a vector of BNRBV is unknown.

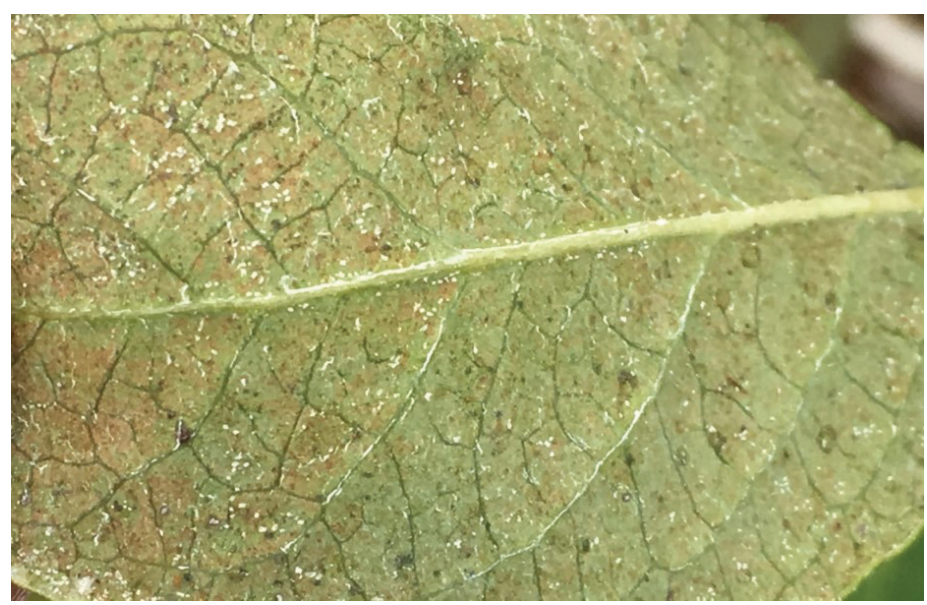

Figure 3. Southern red mite shed skins.

Credits: D. Phillips, UF/IFAS

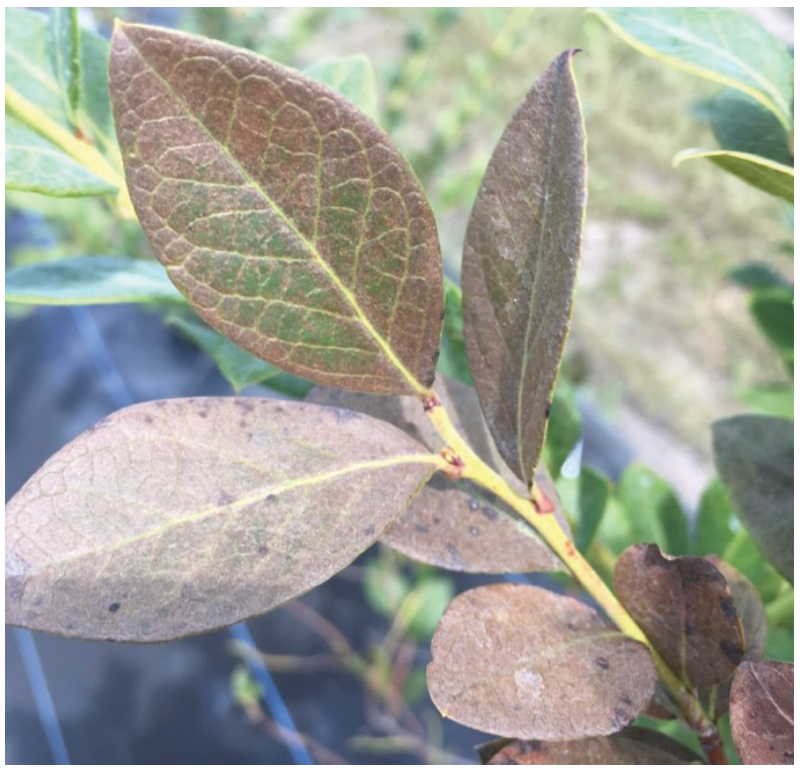

Figure 4. Characteristic bronze-colored blueberry leaves associated with southern red mite damage.

Credits: D. Phillips, UF/IFAS 

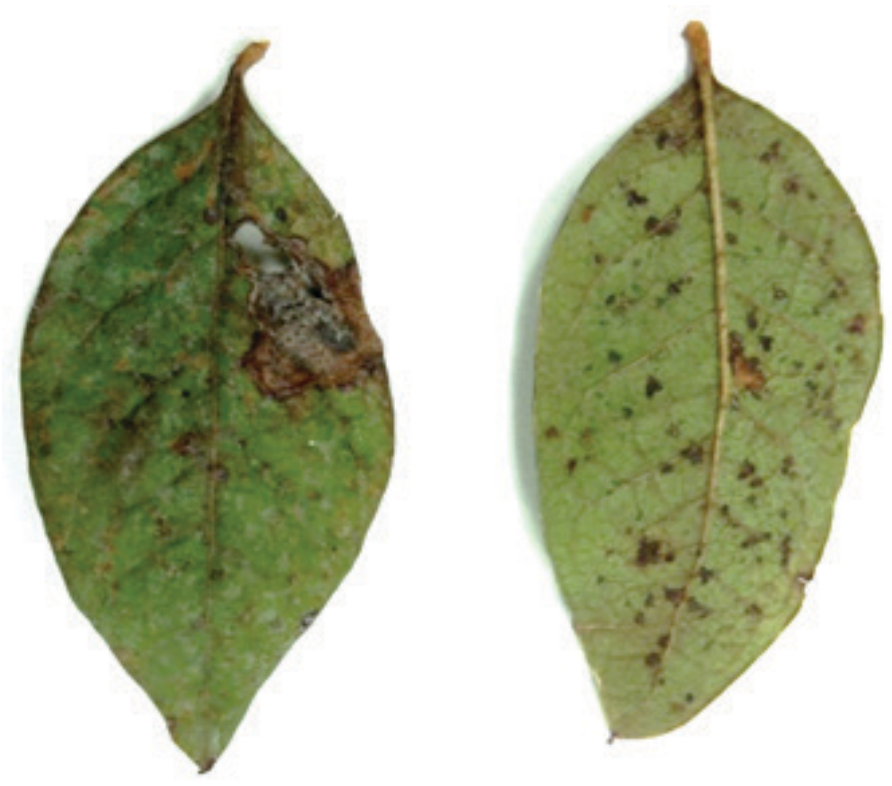

Figure 5. Necrotic brown spots on blueberry leaves caused by false spider mites or flat mites.

Credits: R. Akyazi, University of Ordu, Turkey

\section{Monitoring and Management}

There are multiple differences between the southern red mite and the flat mite. Besides differences in body shape and color, flat mites are smaller, slow-moving, and best seen with hand lenses or under a stereomicroscope. Southern red mites are fast and can be seen with the naked eye on the blueberry leaves. In addition, southern red mites feed all over the underside of leaves and produce a protective web made of silk over the infested surface to protect them from predators, whereas flat mites prefer to feed near the midrib or secondary veins on the underside of leaves without a web.

In general, mite populations tend to flourish during hot, dry conditions. Frequent scouting and collection of leaves are recommended to identify early mite infestations during vegetative growth. Southern red mite can be seen with a 10X hand lens. However, higher magnification (20X) will be necessary to clearly see flat mites' morphological features. Characteristic symptoms of mite feeding such as bronzed leaves (southern red mites) and necrotic spots (flat mites) are also a good indication of mite infestations. However, these symptoms generally appear when moderate to severe infestation levels have already occurred and the risk of defoliation has increased.

Closely examine the underside of leaves with the appropriate magnifying glass (discussed in the previous paragraph) and look for adults, shed skins, and webbing. Another method to scout for the presence of mites is sharply tapping foliage onto a sheet of white paper to observe any adults.
High infestations of southern red mites were detected in October 2018 and 2019 in commercial SHB plantings in north central Florida. Southern red mites have been found infesting various SHB cultivars including 'Avanti', 'Farthing, 'Kestrel', 'Patrecia,' 'Indigocrisp,' 'Meadowlark', and 'Keecrisp' ('Avanti' has been observed to have somewhat higher susceptibility to mite damage), while flat mites have been recorded in 'Abundance,' 'Emerald', and 'Meadowlark'. Additionally, dusty conditions are favorable for mites, and drought-stressed plants can be more susceptible to infestations. Water should be regularly applied to roadways or other dusty areas during hot, dry periods along with sufficient plant irrigation to avoid drought stress, which is particularly important during periods of mite activity.

Predatory mites are an important management tool used for controlling spider mites. Some predatory mites that have been used in fruit systems include Amblyseius fallacis, Galendromus occidentalis, Mesoseiulus longipes, Neoseiulus californicus, and Phytoseiulus persimilis. However, these predators have not been successfully evaluated in blueberry systems.

The flat mite is an important pest of citrus. Its biology and ecological interactions have been studied in that cropping system, as well as most of the management techniques used for its control. Because this mite was only recently reported infesting blueberries, there are no established guidelines for its control in blueberry plantings. Miticides such as Envidor $^{\circledast}$ with the active ingredient spirodiclofen, and Nealta ${ }^{\oplus}$ with the active ingredient cyflumetofen have been reported as successful at controlling B. yothersi in citrus. However, these miticides are not registered for use in blueberries, and there is no available information on their performance against flat mites infesting blueberries.

The southern red mite is now an important pest in both protected and open-field SHB plantings. Two miticides, Magister ${ }^{\circledast}$ with the active ingredient fenazaquin, and Portal $^{\circledR}$ with the active ingredient fenpyroximate, have recently been registered for use in highbush blueberries. These miticides target tetranychids and not specifically southern red mites. The miticides control all developmental stages including larvae, nymphs, and adults of southern red mites. Data from our 2019 field trials (where seven miticides were evaluated) indicate that these two miticides were the best-performing ones in terms of suppressing southern red mite populations and allowing bushes to recover from mite injury. Growers can only make one application per year using Magister ${ }^{\circledR}$ and two applications per year with Portal $^{\circledR}$. Southern red mites can typically be found in SHB plantings in Florida in late August or early September, 
with increased mite populations detected at the beginning of October, continuing through fall and winter months in evergreen systems. Early identification of mite infestations and implementation of management techniques (between August and September) before mites reach high population numbers are recommended to avoid yield impacts.

\section{References}

Akyazi, R., E. A. Ueckermann, and O. E. Liburd. 2017.

"New Report of Brevipalpus yothersi (Prostigmata: Tenuipalpidae) on Blueberry in Florida." Fla. Entomol. 100(4): 731-740.

Amaral, I., G. J. de Moraes, C. C. Melville, and D. J. Andrade. 2018. "Factors Affecting Prevailing Population Levels of Brevipalpus yothersi (Acari: Tenuipalpidae) in Citrus Areas Affected by Citrus Leprosis in the State of Sao Paulo, Brazil." Exp. Appl. Acarol. 74: 395-402.

Childers, C.C., J. V. French, and J. C. V. Rodrigues. 2003. "Brevipalpus californicus, B. obovatus, B. phoenicis and B. lewisi (Acari: Tenuipalpidae): A Review of Their Biology, Feeding Injury and Economic Importance." Exp. Appl.

Acarol. 30: 5-28.

Denmark, H.A., W. C. Welbourn, and T. R. Fasulo. 2012. "Southern Red Mite, Oligonychus ilicis (McGregor) (Arachnida: Acari: Tetranychidae)." Gainesville, FL: Florida Department of Agriculture and Consumer Services, Division of Plant Industry and UF/IFAS Entomology and Nematology Department.

Knihinicki, D., E. Keskula, and G. A. Herron. 1999. “The Southern Red Mite, Another New Pest!” The Nursery Papers 1999. Australia: Nursery Industry Association of Australia. Accessed on April 14, 2020. https://www.greenlifeindustry. com.au/Attachment?Action=Download\&Attachme nt_id=1367

Lopez, L., and O. E. Liburd. 2020. "Injury to Southern Highbush Blueberries by Southern Red Mites and Management Using Various Miticides." Insects. 11(233): 1-10.

Phillips, D. A., N. C. Flor, and P. F. Harmon. 2019. Florida Blueberry Leaf Disease Guide. PP348. Gainesville: University of Florida Institute of Food and Agricultural Sciences. https://edis.ifas.ufl.edu/pp348

Reis, P. R., M. A. Toledo, and F. M. A. Silva. 2014. "Cyazypyr Selectivity for Three Species of Phytoseiid for Coffee and Other Relevant Agricultural Crops in Brazil." Agric. Sci. 5: 298-303.
Roy, A., J. S. Hartung, W. L. Schneider, J. Shao, M. G. Leon, M. J. Melzer, J. J. Beard, G. Otero-Colina, G. R. Bauchan, and R. Ochoa. 2015. "Role Bending: Complex Relationships between Viruses, Hosts, and Vectors Related to Citrus Leprosis, an Emerging Disease." Phytopathology 105: 872-884.

Weibelzahl, E., and O. E. Liburd. 2017. Blueberry Bud Mite, Acalitus vaccini (Keifer) on Southern Highbush Blueberry in Florida. ENY-858. Gainesville: University of Florida Institute of Food and Agricultural Sciences. https://edis.ifas. ufl.edu/in844 